African Journal of Biomedical Research, Vol. 9 (2006); 235 - 237

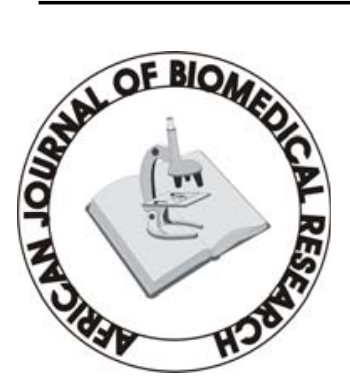

Full-text available at http://www.ajbrui.com http://www.bioline.br/md http://www.ajol.com

Received:

March 2006

Accepted (Revised):

July 2006

Published

September 2006
Short communication

\section{Biochemical changes in serum of Rat treated with aqueous extract of the fruit of Telfairia Occidentalis}

\author{
*Olorunfemi A Eseyin ${ }^{1}$, Arit Ekpo ${ }^{2}$, Iboro Idem $^{2}$ and Arnold \\ C Igboasoiyi ${ }^{1}$
}

1 Department of Pharmaceutical and Medicinal Chemistry, Faculty of Pharmacy, University of Uyo, Nigeria.

2 Department of Biochemistry, College Of Health Sciences , University of Uyo , Nigeria.

\section{ABSTRACT}

The effects of the ethanolic fruit extract of T. Occidentalis on some enzymes and biochemical parameters were evaluated in rats. 100,500 , and $1000 \mathrm{mg} / \mathrm{kg}$ of the extract were administered orally and once daily to three different groups of rats, respectively, for 28days. The fourth group which served as Control received distilled water only. On the $29^{\text {th }}$ day, the rats which had been fasted overnight were dissected under Chloroform anaesthesia and blood was collected directly from their hearts. The blood was allowed to clot and centrifuged to obtain the serum which was kept in a refrigerator at $-4{ }^{\circ} \mathrm{C}$ until used for analysis of the following parameters :alanine and aspartate transaminases, alkaline phosphatase, cholesterol, Triglycerides, creatinine, high density lipoproteins, total and conjugated bilirubin, and total proteins. The fruit extract of the plant significantly elevated the serum concentrations of cholesterol, triglycerides, total proteins, at the three dose levels. The 500 and $1000 \mathrm{mg} / \mathrm{kg}$ doses increased the concentrations of HDL and conjugated bilirubin. While only 100 and $500 \mathrm{mg} / \mathrm{kg}$ doses of the extract reduced the level of total bilirubin. The hypercholesterolemic, hyperproteinemic, hypertriglyceridemic and hyperconjugated bilirubinemic effect of this extract coupled with the increased activity of alkaline phosphatase suggest that the fruit of Telfaira Occidentalis may not be safe for consumption. This is quite contrary to the nutritional usage of the leaf and seed of this plant. (Afr. J. Biomed. Res. 9: 229 - 231

Keywords: Telfaraia occidentalis, pumpkin, fruit, enzymes, cholesterol, bilirubin, rat

*Address for Correspondence: femiabraham@yahoo.com; Phone : +234-8023291687

Abstracted by:

African Index Medicus (WHO), CAB Abstracts, Index Copernicus, Global Health Abstracts, Asian Science Index, Index Veterinarius, Bioline International , African Journals online 


\section{INTRODUCTION}

Telfairia occidentalis commonly known as fluted pumpkin is also known as fluted gourd, Costillada (Spanish), Krobonko (Ghana), and Gonugbe (Sierra Leone). The plant belongs to the Cucurbitaceae family and is cultivated across lowland humid tropics of West Africa - Nigeria, Ghana, Sierra Leone -mainly for its nutritional value (Axtell,1992). The leaves are eaten as vegetables while the seeds are either roasted or ground for other food preparations. Apart from the nutritional (Okoli,et al,1983), agricultural and industrial importance (Akoroda,1990) the plant is also medicinally useful. It possesses antiinflammatory(Oluwole,2003), antibacterial (Odoemena,1995), erythropoietic (Ajayi et al,2000) ,anticholesterolemic (Eseyin et al,2005a), and antidiabetic (Eseyin et al, 2000; Eseyin et al,2005b) activities.

The fruits of T.Occidentalis are among the largest known. The ripe fruit contains up to $13 \%$ oil. While various investigations have been carried out in the leaf, stem, seed and root of this plant, very little work has been done on the fruit. This work is therefore an attempt to kickstartresearches on the fruit of Telfairia Occidentalis so as to explore its medicinal value

\section{MATERIALS AND METHODS}

Plant Collection and Extraction: The fruits of Telfairia Occidentalis were obtained from the medicinal plant farm of the Faculty of Pharmacy ,University of Uyo, Nigeria .The fruits were sliced open and the pulp and seeds evacuated. The fruits were then chopped into small bits. 4Litres of 96\% ethanol was poured into a container containing $2.5 \mathrm{~kg}$ of the fruit material and left for 72hours. The extract was filtered and concentrated in vacuo. The residue was dried in a dessicator.

Administration of Extract to Animals :Twenty Wistar albino rats of both sexes obtained from the animal house of the University of Uyo were used. The rats had free access to water and standard palletized feed, and they were kept in the care of experienced animal technicians. Prior to the administration of extract, the rats were fasted overnight. They were divide into four equal groups.
100,500 , and $1000 \mathrm{mg} / \mathrm{kg}$ of the fruit extract was orally administered once daily for 28days to groups 1,2 , and 3 , respectively. While group 4 (control) received distilled water only instead of the extract.

Collection of Blood: On the $29^{\text {th }}$ day, blood was collected from the heart of the overnight fasted rats under chloroform anaesthesia. The blood collected was allowed to clot and centrifuged to obtain the serum. The blood serum was kept in a refrigerator at $0-4^{\circ} \mathrm{C}$ until it was used.

Estimation of Bimolecules: Appropropriate commercias kits (Randox Laboratories, U. K.) were used to determine the concentrations of alanine and aspartate transaminases (ALAT and ASAT), alkaline phosphatase, cholesterol, Triglycerides, creatinine, High density lipoproteins (HDL), total and conjugated bilirubin, and total proteins.

Alanine Transaminase (ALAT): The method involves the monitoring of the concentration of pyruvate hydrazone formed with 2,4-einitrophenyl hydrazine

Aspartate aminotransferase(ASAT): The principle of the method used involved monitoring the concentration of oxaloacetate hydrazone formed with 2,4,-dinitrophenyl hydrazine

Alkaline phosphatase (Phenolphthalein Monophoshate method): This method is based on the principle that serum alkaline phosphatase hydrolyzes a colourless substrate of phenolphthalein that results in phosphoric acid and phenolphthalein at alkaline PH.values. The pinkly coloured product is measured colorimetrically at $550 \mathrm{~nm}$.

Triglycerides: This involves the enzymatic colorimetric test of glycerol phosphate oxidase method

Total Cholesterol: This was carried out by the enzymatic colorimetric chod-PAP method

HDL-Cholesterol: high density lipoprotein (HDL) separated from chylomicrons. Very low density lipoproteins (VLDL) and low density lipoproteins (LSL) by the addition of a phosphotungstic and magnesium chloride (precipitating reagent) to the serum. After centrifugation, the cholesterol content was determined by the enzymatic colorimetric method.

Total Protein: This was done using the Biuret method. 
Table 1 :

Effects of the fruit extract of Telfairia Occidentalis on some biochemical parameters in rat $(n=5 * P<0.05)$

\begin{tabular}{|c|c|c|c|c|c|}
\hline Biomolecules & Control & $1000 \mathrm{mg} / \mathrm{kg}$ & $500 \mathrm{mg} / \mathrm{kg}$ & $100 \mathrm{mg} / \mathrm{kg}$ & $\mathbf{F}$ \\
\hline Cholesterol (mmol/L) & $4.262 \pm 0.214$ & $5.9772 * \pm 0.139$ & $6.3156 * \pm 0.21$ & $5.5916 \pm \quad 0.562$ & 39.7 \\
\hline Triglycerides mmol/L) & $1.578 \pm 0.166$ & $1.8308 * \pm 0.0356$ & $1.7824 * \pm 0.06$ & $1.9132 * \pm 0.0949$ & 8.34 \\
\hline Creatinine (mmol/L) & $126.4 \pm 49.67$ & $65.2 \pm 18.0$ & $112.2 \pm 39.19$ & $81.6 \pm 38.2$ & 2.21 \\
\hline ALAT (U/L) & $22.2 \pm 8033$ & $19.4 \pm 7.90$ & $28.2 \pm 1.60$ & $25.0 \pm \pm 5.06$ & 1.70 \\
\hline ASAT (U/L) & $18.0 \pm 3.35$ & $22.0 \pm 4.38$ & $18.0 \pm 3.35$ & $21.6 \pm 5.20$ & 1.47 \\
\hline HDL (mg/kg) & $1.422 \pm 0.118$ & $1.802 * \pm 1.55$ & $1.314 \pm 0.136$ & $1.566 \pm 0.228$ & 7.54 \\
\hline Total Bilirubin $(\mu \mathrm{mol} / \mathrm{L})$ & $13.026 \pm 1.997$ & $19.31 \pm 8.33$ & $7.40 * \pm 1.74$ & $8.07 * \pm 3.33$ & 5.16 \\
\hline Conjug. Bilirubin $(\mu \mathrm{mol} / \mathrm{L})$ & $3.986 \pm 0.63$ & $21.09 * \pm 10.09$ & $6.74 * \pm 2.11$ & $5.965 \pm 3.159$ & 7.76 \\
\hline Total Proteins (g/L) & $49.402 \pm 1.112$ & $67.868 * \pm 1.89$ & $65.168 * \pm 3.229$ & $64.424 * \pm 3.70$ & 51.55 \\
\hline Alkaline Phosphatase (U/L) & $27.2 \pm 1.60$ & $35.6 * \pm 1.019$ & $33.6 * \pm 2.87$ & $34.0 * \pm 2.83$ & 11.85 \\
\hline
\end{tabular}

Creatinine: Modified Jaffe's method was used. Creatinine which is a hydride of creatine reacts with alkaline sodium picrate to form a red complex which can be determined photometrically.

Total and Conjugated Bilirubin: This was based on colorimetric method

Statistical Analysis: Data were expressed as Mean + SEM and were analysed by two way ANOVA and Scheffe's post test. $\mathrm{P}<0.05$ was taken as significant

\section{RESULTS AND DISCUSSION}

As could be seen from Table 1: 100,500, and $1000 \mathrm{mg} . / \mathrm{kg}$ of the extract significantly elevated the serum concentration of Cholesterol (5.5916, 6.3156, and 5.9772 mmole/L), Triglycerides (1.9132, 1.7824 , and $1.8308 \mathrm{mmol} / \mathrm{L})$, total proteins $(64.424$, 65.168, and $67.868 \mathrm{mmol} / \mathrm{L}$ ), and alkaline phosphatases (34.0, 33.6, and 35.6 U/L). HDL was elevated significantly only by $1000 \mathrm{mg} / \mathrm{kg}$ dose $(1.802 \mathrm{mmol} / \mathrm{L})$,conjugated bilirubin by 500 and $1000 \mathrm{mg} / \mathrm{kg}$ doses $(6.74$ and $21.09 \mathrm{mmol} / \mathrm{L}$, respectively). Only the 100 and $500 \mathrm{mg} / \mathrm{kg}$ doses significantly reduced serum level of total bilirubin (i.e. 8.07 and $7.40 \mathrm{mmol} / \mathrm{L}$ ) compared to control $(13.03 \mathrm{mmmol} / \mathrm{L})$.It is obvious from the above data that the fruit extract caused hypercholesterolemia, hypertriglyceridemia and increased alkaline phosphatase level. While hyperproteinemia is indicative of inflammatory process, conjugated bilirubinemia is indicative of lockage of the hepatic or common bile ducts. Elevated serum level of alkaline phosphatase is diagnostic of bone disorders while cholesterolemia occurs in affected liver.
It could therefore be concluded that the fruit extract had a damaging effect on the rat liver and bones, and may therefore not be safe for consumption for a prolonged period ,except probably at very low dose .

\section{REFERENCES}

Ajayi OI,Ajayi TC, Omokaro .ED, Halim NKD (2000): Erythropoietic value of $T$. Occidentalis in rabbit. A preliminary study. Nig. J. Physiol. Sci. 16 (1-2): 1-3

Akoroda MO (1990): Ethnobotany of Telfairia Occidentalis (Cucurbitaceae) among Igbos of Nigeria .Economic Botany 44(1),29-39

Axtell BL (1992): Minor Oil Crops. FAO Agricultural Services Bulletin No 94.FAO of The United Nations.

Eseyin OA, Igboasoiyi AC, Oforah E, Ching P, Okoli BC (2005a) Effect of extract of T. Occidentalis leaves on some biochemical parameters in rat. Glob. J. Pure and Appl. Sci. 11(1):85-87

Eseyin OA, Igboasoiyi AC, Oforah E, Nkop, Agboke A (2005b) Hypoglycemic activity of T. Occidentalis in rats. J. Pharm. and Bioresources 2(1):36-42

Eseyin OA, Oforah E, Dooka BD (2000) Preliminary study of the hypoglycemic action of the extract of leaf of T. Occidentalis in normoglycemic guinea pigs. Global J.Pure and Appl. Sci. 6(4):639-641

Odoemena CS, Essien JP (1995) Antibacterial activity of the root extract of T. Occidentalis .West Afr. J.Biol. and Appl. Chem.40:1-4

Okoli BE, Mgbeogu CM (1983) Fluted Pumpkin , Telfairia Occidentalis: West African Vegetable Crop. Economic Botany,37 (2) 145-149

Oluwole FS, Falade A.O, Ogundipe 0.0 (2003): Antiinflammatory effect of some common Nigeria vegetables . Nig. J. Physiol. Sci. 18(1-2):35-38 